Pak. j. sci. ind. res. Ser. A: phys. sci. 201356 (2) 70-85

\title{
Kinetic and Equilibrium Study of Adsorption of Di-Azo Dyes on Commercial Activated Carbon
}

\author{
Emad Abdulilah Saleh Al-Hyali* and Ra'ed Tariq Ghanim Al-Abady \\ Chemistry Department, College of Education, University of Mosul, Mosul, Iraq
}

(received June 13, 2011; revised May 1, 2012; accepted July 16, 2012)

\begin{abstract}
This research work is concerned with studying the adsorption of a number of di-azo dyes on commercial activated carbon (CAC). The synthesized dyes vary in their structures by the central parts, which are either ortho, meta or para phenylene diamine. This variation affects the linearity of molecules, their spatial arrangement and electron movement throughout the molecule by resonance. Factors affecting adsorption process, such as the effect of contact time, initial concentration, $\mathrm{pH}$ of the adsorption medium, adsorbent dose, effect of solvent and temperature were studied. The results indicated that, the adsorption process is fast in the first $10 \mathrm{~min}$, then gradually decreased with time and approaches maximum within 70-80 min for all the studied dyes. The increase of initial concentration and temperature decreased the adsorption efficiency. The results also shows that, the adsorption is found to be more efficient at low $\mathrm{pH}$ value. The increase of the adsorbent dose increases the adsorption efficiency and decreases its capacity. The variation of solvent (ethanol-water ratio) indicates that the decrease of dielectric constant lowers the adsorption efficiency. The study included application of three adsorption isotherms; Freundlich, Langmuir and Tempkin on the experimental data of the studied systems. The results indicated that, Freundlich isotherm fits better the adsorption data. Kinetic analysis of the adsorption data was also conducted by employing 4 kinetic models; pseudo first order and pseudo second order, Elovich and intra particle diffusion equations. The results obtained conclude that, the studied systems follow the Pseudo second order model.
\end{abstract}

Keywords: kinetic study, equilibrium of adsorption, di-azo dyes, activated carbon

\section{Introduction}

Dyes are organic compounds; usually have a complex aromatic molecular structure making them stable and resistant to biodegradation (Mohorcic et al., 2004).

Azo dyes represent the largest class of commercially produced dyes, in which the chromophores are the azo group (Sutherland, 2004; Wallace, 2001). Synthetically, they were produced in a huge amounts, exceeding $(500,000)$ tons annually (Lewis, 1999), and were used in various industrial fields including the textile industry. The high stability and distinguishing colour of azo dyes, especially those with di and multiple azo groups attracted the attention of many manufactures and become valuable for such industry. The excess of dye remains in the effluent after dyeing process is commonly forms a wastewater with concentration ranging (from 10 to $200 \mathrm{~g} / \mathrm{L}$ ) of dyestuffs (Van der Zee, 2002).

Since some azo dyes and their degradation products are toxic and carcinogenic, their disposal into wastewater without advanced treatment creates a dramatic

*Author for correspondence; E-mail: emadabd2006@yahoo.com source of pollution and damages the aquatic life. For this reason, a proper treatment is needed and dyes removal from wastewater became essential.

Intensive research work was carried out concerning treatment of such problems and aiming for providing a suitable technology for environmental protection. Various physiochemical and biological methods are described in the literature which can be employed for removing dyes from wastewater including; filtration (Dushankov et al., 1995), chemical precipitation, flocculation (Vandevivere et al., 1998; Smith et al., 1993), ion exchange (Annadurai et al., 2002; Slokar and Marechal, 1998), membrane separation, flotation (Dushankov et al., 1995) and adsorption (Suteu and Bilba, 2005). Each of these techniques has its advantages and limitations regarding the environmental conditions. Its technical and economic feasibility is determined by different measures related to the dye type, wastewater composition, and cost. Sometimes, the use of one individual technique is not sufficient for achieving complete decolourization; therefore, the dye removal strategy may involve more than one technique (Suteu and Bilba, 2005). 
Adsorption seems to be the most potential technique for dye removal from wastewater because of its simple design, initial cost, ease of operation and insensitivity to toxic substances (Eren and Acar, 2006). The use of various low cost materials as adsorbents for the removal of dyes from wastewater such as, chitin (McKay et al., 1982), natural clay (El-Geundi, 1991), rice husk(Malik, 2003) etc. have been investigated. Activate carbon remains the most effective and widely used adsorbent for the dye uptake from aqueous solutions because of its large surface area, dye binding capacity and regeneration properties (Yasin et al., 2007).

The rate of adsorbate uptake from solution onto the adsorbent solid surface after surmounting all the molecular forces, those trying to preclude the adsorption process is termed as adsorption kinetic. The kinetic data are valuable for determining the period required to reach equilibrium and assessing the adsorbent efficiency for adsorbate removal from effluents (Hameed, 2009; Ahmed et al., 2007). Such data can also provide a clue for understanding the mechanism of adsorption, which is essential for improving the efficiency of such process and optimization of various parameters in dye recovery (Eren and Acar, 2006) for this reason, several research groups have focused their efforts on developing such studies (Hameed, 2009; AL-Hyali and Al-Jarjari, 2008; Ahmed et al., 2007; Yasin et al., 2007; Ho, 2006; Malik, 2003).

Kinetic models. The significance of the kinetic analysis of adsorption data lies in that, it provides a valuable insight into the adsorption pathways and mechanism of the attachment of adsorbate onto solid surfaces of adsorbents, which involve mass transfer and chemical reactions, those important for determining the efficiency of adsorption process.

The kinetic data of the adsorption of diazo dyes considered in this study onto a commercial activated carbon (CAC) were analyzed using four different kinetic models, namely; Pseudo first order and Pseudo second order, Elovich equation and intra particle diffusion model rate equation.

Pseudo first order model. It was suggested by Lagergren (Lagergren, 1898), which can be represented as in equation (1):

$$
\frac{\mathrm{dq}_{\mathrm{t}}}{\mathrm{dt}}=\mathrm{k}_{1}\left(\mathrm{q}_{\mathrm{e}}-\mathrm{q}_{\mathrm{t}}\right)
$$

Where, $\left(\mathrm{k}_{1} / \mathrm{min}\right)$ is the Pseudo first order rate constant, $\mathrm{q}_{\mathrm{e}}$ and $\mathrm{q}_{\mathrm{t}}(\mathrm{mg} / \mathrm{g})$ represent the adsorption capacities (amount of adsorbed dye on unit mass of carbon) at equilibrium and time $(\mathrm{t})$, respectively. The integrating rate law by applying the initial condition of $t=0$ to $t=t$ and $\mathrm{q}_{\mathrm{t}}=0$ to $\mathrm{q}_{\mathrm{t}}=\mathrm{q}_{\mathrm{t}}$, equation (1) becomes:

$$
\log \left(\mathrm{q}_{\mathrm{e}}-\mathrm{q}_{\mathrm{t}}\right)=\log \mathrm{q}_{\mathrm{e}}-\frac{\mathrm{k}_{1}}{2.0303} \mathrm{t} .
$$

The adsorption data of the considered system fits this model, if the plot of $\log \left(\mathrm{q}_{\mathrm{e}}-\mathrm{q}_{\mathrm{t}}\right)$ versus time gave a linear relationship with correlation coefficient $\left(R^{2}\right)$ close to unity, and the experimental $\left(\mathrm{q}_{\mathrm{e}}\right)$ value was consistent with the value calculated from the intercept of the plot.

Pseudo second order model. This model is first applied by Ho et al. (1996), to assess the kinetic of adsorption data of heavy metal adsorption. It showed that, the rate depends on the adsorption capacity on the solid and not on the concentration of the adsorbate (Eren and Acar, 2006; Ho, 2006).

The Pseudo second order kinetic model can be represented as in equation (3); (Ho et al., 1996):

$$
\frac{d q_{t}}{d t}=k_{2}\left(q_{e}-q_{t}\right)^{2} .
$$

Where, $\mathrm{k}_{2}$ is the rate constant of Pseudo second order adsorption $(\mathrm{g} / \mathrm{mg} / \mathrm{min})$. The integrated linear from of equation (3) is (McKay and Ho, 1999):

$$
\frac{\mathrm{t}}{\mathrm{q}_{\mathrm{t}}}=\frac{1}{\mathrm{k}_{2} \mathrm{q}_{\mathrm{e}}^{2}}+\frac{1}{\mathrm{q}_{\mathrm{t}}} \mathrm{t} .
$$

This model is applicable only when the value of $t / q_{t}$ is linearly correlated with time and the value of calculated $\mathrm{q}_{\mathrm{e}}$ is well fit the experimental data.

Elovich kinetic model. The Elovich as modified by Chien and Clayton (1980), is the rate equation based on the adsorption capacity commonly expressed as in equation (5); (Chien and Clayton, 1980):

$$
\frac{d q_{t}}{d t}=\alpha \exp \left(-\beta q_{t}\right)
$$

Where, $\alpha(\mathrm{mg} / \mathrm{g} / \mathrm{min})$ is the initial rate of adsorption, $\beta(\mathrm{g} / \mathrm{mg})$ the adsorption constant during any experiment related to extent of surface coverage and activation energy of chemisorptions. 
The Elovich equation can be simplified by assuming $\alpha \beta t>>t$ by applying the boundary conditions $q_{t}=0$ at $\mathrm{t}=0$ and $\mathrm{q}_{\mathrm{t}}=\mathrm{q}_{\mathrm{t}}$ at $\mathrm{t}=\mathrm{t}$, equation (5) becomes:

$$
\mathrm{q}_{\mathrm{t}}=\frac{1}{\beta} \ln =(\alpha \beta)+\frac{1}{\beta} \ln \mathrm{t}
$$

The plot of $q_{t}$ versus $\ln (t)$ gives a linear relationship. The value of $\alpha$ and $\beta$ can be calculated from the intercept and slope, respectively.

Intra particle diffusion model. This model was first developed by Weber and Morris (1963) and used to explore the possibility of intra-particle diffusion resistance affecting the adsorption. It can be represented by the relation between $\mathrm{q}_{\mathrm{t}}$ and the square root of time $\left(\mathrm{t}^{1 / 2}\right)$, as in equation (7):

$$
\mathrm{q}_{\mathrm{t}}=\mathrm{K}_{\text {diff }} \mathrm{t}^{1 / 2}+\mathrm{C}
$$

Where, $K_{\text {diff }}(\mathrm{mg} / \mathrm{g} / \mathrm{min})$ is the diffusion rate constant and $\mathrm{C}(\mathrm{mg} / \mathrm{g})$ is a value proportional to boundary layer thickness (Kannan and Sundaram, 2001).

According to this model, if the plot of adsorption capacity $\left(q_{t}\right)$ versus $t^{1 / 2}$ is linear, the Intra particle diffusion is involved and if the line passes through the origin, diffusion into the adsorbent pores is the only controlling step.

\section{Materials and Methods}

All the experiments in this study were performed as batch method.

Adsorbent. The adsorbent used in this study for removing dyes from their aqueous solutions is a commercial powdered activated carbon with particle size of $50 \mu \mathrm{l}$ and ash ratio less than $2 \%$. The CAC was dried at $100{ }^{\circ} \mathrm{C}$ for $24 \mathrm{~h}$ before used and kept in a sealed bottle for further use.

Adsorbate. Five di-azo dyes were used as adsorbate in this study. These dyes vary in structure by their central parts, which are either ortho, meta or para phenylene diamine. They were synthesized from the reaction of phenylene diamine with the resorcinol or $m$-amino phenol with (1:2) mole ratio, via dizonium salts, respectively (AL-Abady, 2010; Volgel, 1964), as in the following equation:
The chemical compositions and other physical properties of the synthesized dyes are listed in Table 1.

The starting materials used for the preparation of these dyes and other chemicals such as $o, m$, and $p$-phenylene diamine, $m$-amino phenol, ethanol, $\mathrm{NaNO}_{2}, \mathrm{HCl}$ and $\mathrm{NaOH}$ are of analytical grade and supplied by BDH and Fluka chemical companies.

Analytical method. The dye concentrations were monitored by measuring the absorbance of the filtrate of each dye at its $\lambda_{\max }$ ( indicated in Table 1). By employing a single beam, UV-Vis spectrophotometer (Cecil-CE.1021) after separation of the adsorbent from dye solution by filtration. A calibration curve for each dye was constructed prior to the measurement by using various solution of known concentrations and within the detection limit of the dye according to Beers Law $(\mathrm{A}=\varepsilon \mathrm{b} C)$.

The amount of dye bound on the unit volume of adsorbent was estimated from the difference between the initial concentration of dye and free (unbound) dye concentration left in the solution.

Equilibrium study. As batch mode experiments, samples of $2 \mathrm{~g}$ of CAC were equilibrated with $1 \mathrm{~L}$ of solutions containing various concentrations of each dye (35-245 mg/L) under continuous stirring.

The initial $\mathrm{pH}$ of the solution was adjusted by employing diluted solutions of $\mathrm{NaOH}$ or $\mathrm{HCl}$ and pH meter of the (pH 720 WTW 82362 Weilheim) type.

The study is conducted at various temperatures (20, $30,40,50$ and $60^{\circ} \mathrm{C}$ ). The temperature was controlled by thermostatic water bath shaker (Julabo SW23). Constant rate of shaker (90 rpm) was used throughout the study. The samples were filtered to isolate the carbon particles. The residual dye concentration was determined spectrophotometrically at the maximum wave length corresponding to each dye.

The amount of adsorbed dye is evaluated in terms of the adsorption capacity $\left(\mathrm{q}_{\mathrm{e}}, \mathrm{mg}\right.$ of dye per gram

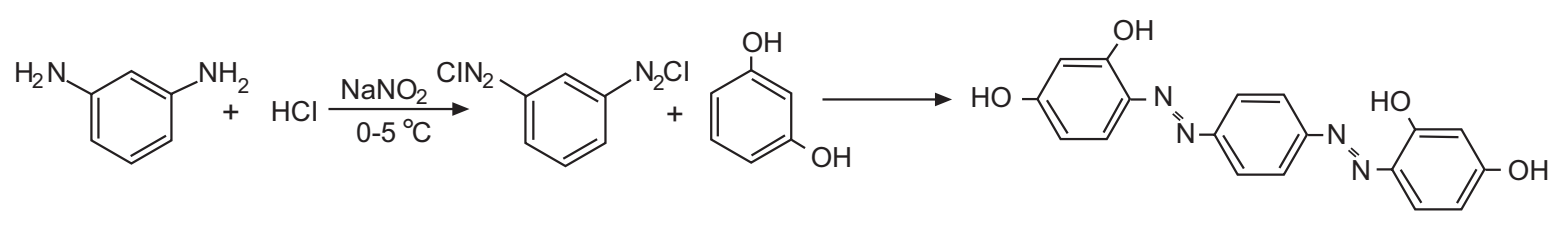


of adsorbent), which can be calculated by equation (8):

$$
\mathrm{q}_{\mathrm{e}}=\frac{\mathrm{C}_{\mathrm{i}}-\mathrm{C}_{\mathrm{e}}}{\mathrm{M}} \times \frac{\mathrm{V}}{1000}
$$

And by the percent of adsorbed dye (Ads. \%) as,

$$
\text { Ads. } \%=\frac{C_{i}-C_{e}}{C_{i}} \times 100
$$

Where, $\mathrm{C}_{\mathrm{i}}$ and $\mathrm{C}_{\mathrm{e}}$, are the initial and equilibrium concentrations $(\mathrm{mg} / \mathrm{L})$ of the dye solutions. $\mathrm{M}$ is the amount of adsorbent $(\mathrm{g})$ and $\mathrm{V}$ is the volume of the agitated dye solution $(\mathrm{mL})$.

Kinetic study. The effect of contact time was determined by carrying out series of experiments. In each of them, dye solution with initial concentration $87 \mathrm{mg} / \mathrm{L}$ was agitated with CAC (dose $2 \mathrm{~g} / \mathrm{L}$ ) at different time intervals. The temperature of solution was held constant $\left(20^{\circ} \mathrm{C}\right)$ by using thermostatic bath shaker at constant rate of stirring $(90 \mathrm{rpm})$. The samples were filtered and the residual dye concentrations were determined spectrophotometrically at the $\lambda_{\max }$ of the dye under study.

The effect of contact time experiments were repeated at various initial concentrations of dye $(60,87,100$ and $120 \mathrm{mg} / \mathrm{L}$ ) and the data were tested to fit the kinetic models selected for achieving this study.

\section{Results and Discussion}

Effect of adsorption dose. Two dyes, 1,3DHAB and 1,4HAAB, with initial concentrations 87 and $192 \mathrm{mg} / \mathrm{L}$, respectively were selected for this study. The investigation was carried out at different doses of adsorbent (0.8 - $6 \mathrm{~g}$ of CAC per liter of dye solution), $20^{\circ} \mathrm{C}$ and $\mathrm{pH}=7$. The results obtained are shown in Fig. 1a-b. It indicates that, the increase of adsorbent dose increases the adsorption efficiency (\%Ads), but decreases the adsorption capacity $\left(\mathrm{q}_{\mathrm{e}}, \mathrm{mg} / \mathrm{g}\right)$. This can be readily

\begin{tabular}{|c|c|c|c|c|c|}
\hline Dye (Abbreviation) & Structure & Colour & $\begin{array}{l}\text { M.P. } \\
\left({ }^{\circ} \mathrm{C}\right)\end{array}$ & $\begin{array}{l}\lambda_{\max } \\
(\mathrm{nm})\end{array}$ & $\begin{array}{l}\varepsilon_{\max } \\
\mathrm{L} / \mathrm{mol} / \mathrm{cm}\end{array}$ \\
\hline $\begin{array}{l}\text { 1,4-di(2,4-dihydroxy } \\
\text { phenyl azo) benzene } \\
(1,4 \mathrm{DHAB})\end{array}$ & & Dark grey & $165-167$ & 421 & 29460 \\
\hline $\begin{array}{l}\text { 1,3-di(2,4-dihydroxy } \\
\text { phenyl azo) benzene } \\
(1,3 \mathrm{DHAB})\end{array}$ & & Black & $207-208$ & 390 & 25590 \\
\hline $\begin{array}{l}\text { 1,4-di(2-amino 4-hydroxy } \\
\text { phenyl azo) benzene } \\
(1,4 \mathrm{HAAB})\end{array}$ & & Dark red & $256-258$ & 449 & 19750 \\
\hline $\begin{array}{l}\text { 1,2-di(2-amino 4-hydroxy } \\
\text { phenyl azo) benzene } \\
(1,2 \text { HAAB })\end{array}$ & & Dark grey & $103-105$ & 440 & 17760 \\
\hline $\begin{array}{l}\text { 1,3-di(2-amino 4-hydroxy } \\
\text { phenyl azo) benzene } \\
(1,3 \text { HAAB })\end{array}$ & & Dark grey & $101-103$ & 455 & 17760 \\
\hline
\end{tabular}

Table 1. Chemical composition, physical properties and molar absorbtivity $\left(\varepsilon_{\max }\right)$ of the synthesized dyes 

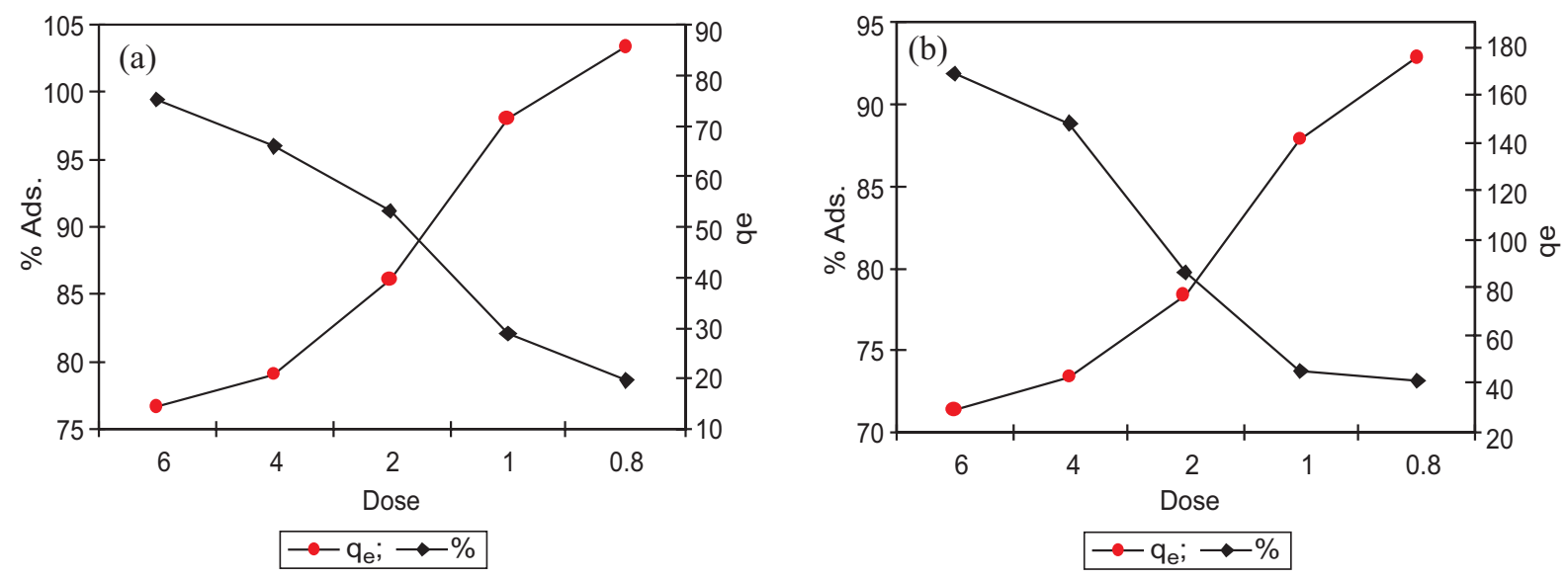

Fig. 1a-b. Relation between adsorption capacity ( $\mathrm{mg} / \mathrm{g})$, adsorption efficiency and adsorbent dose (mg/g) of two azo dyes; (a) 1,3DHAB; (b) 1,4-HAAB.

illustrated; the increase of adsorbent dose increases the active sites available for adsorption on the carbon surface which in turn increases the percentage of dye adsorbed.

The decrease in adsorption capacity with the increase of adsorbent dose is apparently because of the instauration of the additional adsorption sites through adsorption process (Eren and Acar, 2006; Yu et al., 2003; Shukla et al., 2002).

Effect of contact time. The effect of contact time was investigated at initial concentration of $87 \mathrm{mg} / \mathrm{L}$, neutral medium ( $\mathrm{pH}=7)$, carbon dose $2 \mathrm{~g} / \mathrm{L}$ and $20{ }^{\circ} \mathrm{C}$. The variations of adsorption efficiency with time for the studied dyes are shown in Fig. 2.

The variation of the adsorption efficiency with time portrayed in Fig. 2 shows that the adsorption process proceeded in two stages; an initial rapid stage represented by the first $10 \mathrm{~min}$ being very sharp. In this stage $70-80 \%$ of the dyes were removed from solution by CAC. This stage is followed by a slower one in which the uptake rate is gradually decreased with time and reaches equilibrium with in $70-80 \mathrm{~min}$. The time $80 \mathrm{~min}$ is used for further studies.

The curve representing the variation of adsorption ratio of the dye 1,3HAAB with time shows different adsorption pattern. This could be attributed to the non linear shape of the molecule, in addition to that, the electronic distribution through the resonance effect is restricted on two rings only in contrast to the other molecules in which the mesomeric effect is distributed over all the three rings.
Effect of initial concentration. The importance of initial concentration lies in that, it may provide an important driving force to overcome all the mass transfer resistances of the dye between the aqueous and solid phases.

The effect of varying initial concentrations of the dye on adsorption efficiency is tested in the range of 35 to $245(\mathrm{mg} / \mathrm{L})$, while keeping all other parameters constant. The results obtained are listed in Table 2. The adsorption capacity and efficiency are calculated as in equations (8) and (9), respectively.

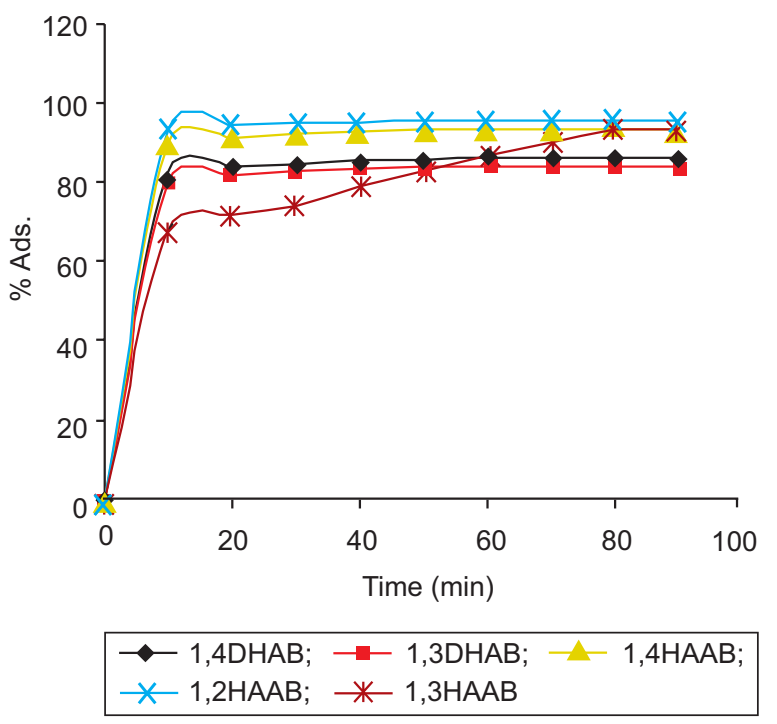

Fig. 2. Variation of adsorption efficiency with time for the considered dyes. 
The results of Table 2 show that, the removal of the studied dyes showed the same trend of variation. The adsorption efficiency of dye on activated carbon is highly dependent on the initial concentration. The amount of adsorbed dye is increased with the increase of initial concentration, while the adsorption efficiency is decreased. This could be attributed to the increase of competition among dye molecules to be adsorbed on a constant number of active sites available for adsorption on a certain amount of adsorbent. This competition decreases the binding energy between the dye and the solid surface, and preclude the adsorption process as a result (Shah et al., 2009; Sharma and Goyal et al., 2009). This result indicates that, the adsorption of such dyes on $\mathrm{CAC}$ is more efficient at low concentration.

Effect of initial pH. The $\mathrm{pH}$ of an aqueous medium is an important factor that could affect the uptake efficiency of a dye by activated carbon, since the chemical characteristics of functional groups of both dye structures and carbon surface can be affected by the variation of $\mathrm{pH}$.

Table 2. Effect of initial concentration on adsorption capacity and efficiency

\begin{tabular}{lllll}
\hline \hline Dye & $\mathrm{C}_{\mathrm{i}}(\mathrm{mg} / \mathrm{L})$ & $\mathrm{C}_{\mathrm{e}}(\mathrm{mg} / \mathrm{L})$ & $\mathrm{q}_{\mathrm{e}}(\mathrm{mg} / \mathrm{g})$ & $\%$ Ads. \\
\hline $1,4 \mathrm{DHAB}$ & 35 & 4.131 & 15.435 & 88.20 \\
& 87 & 11.960 & 37.520 & 86.25 \\
& 140 & 21.595 & 59.203 & 84.58 \\
& 192 & 31.993 & 80.004 & 83.34 \\
$1,3 \mathrm{DHAB}$ & 245 & - & - & - \\
& 35 & 4.128 & 15.436 & 88.21 \\
& 87 & 12.517 & 37.242 & 85.61 \\
& 140 & 23.986 & 58.007 & 82.87 \\
& 192 & 37.430 & 77.285 & 80.51 \\
& 245 & - & - & - \\
$1,4 \mathrm{HAAB}$ & 35 & 1.057 & 16.972 & 96.98 \\
& 87 & 5.413 & 40.794 & 93.78 \\
& 140 & 12.654 & 63.673 & 90.96 \\
& 192 & 25.659 & 83.171 & 86.64 \\
& 245 & 42.847 & 101.077 & 82.51 \\
$1,2 \mathrm{HAAB}$ & 35 & 0.460 & 17.270 & 98.69 \\
& 87 & 3.301 & 41.850 & 96.21 \\
& 140 & 9.728 & 65.136 & 93.05 \\
& 192 & 18.505 & 86.748 & 90.36 \\
& 245 & 30.408 & 107.296 & 87.59 \\
& 35 & 1.402 & 16.799 & 96.00 \\
& 87 & 5.377 & 40.812 & 93.82 \\
& 140 & 14.754 & 62.623 & 89.46 \\
& 192 & 29.524 & 81.238 & 84.62 \\
& 45 & 45.901 & 99.550 & 81.26 \\
\hline \hline
\end{tabular}

This investigation is carried out by varying the initial $\mathrm{pH}$ from 4 to 11 , under a constant initial dye concentration of $87 \mathrm{mg} / \mathrm{L}$, carbon dosage of $2 \mathrm{~g} / \mathrm{L}$ and constant temperature $\left(20^{\circ} \mathrm{C}\right)$. The dependence of the removal capacity of CAC to adsorb the dyes considered in this study on $\mathrm{pH}$ is presented in Table 3 .

Table 3. Effect of $\mathrm{pH}$ medium of dye on adsorption capacity and efficiency, initial concentration of dye is $87 \mathrm{mg} / \mathrm{L}, \mathrm{CAC}$ dose $2 \mathrm{~g} / \mathrm{L}$ and $20^{\circ} \mathrm{C}$

\begin{tabular}{lllll}
\hline \hline Dye & $\mathrm{pH}$ & $\mathrm{C}_{\mathrm{e}}(\mathrm{mg} / \mathrm{L})$ & $\mathrm{q}_{\mathrm{e}}(\mathrm{mg} / \mathrm{g})$ & \%Ads. \\
\hline $1,4 \mathrm{DHAB}$ & 4 & 4.418 & 41.541 & 94.95 \\
& 6 & 9.412 & 41.291 & 89.18 \\
& 7 & 11.894 & 37.803 & 86.41 \\
& 9.4 & 14.507 & 36.496 & 83.42 \\
& 11 & 19.449 & 33.776 & 61.17 \\
$1,3 \mathrm{DHAB}$ & 4 & 1.318 & 43.091 & 98.49 \\
& 6 & 9.860 & 38.57 & 88.67 \\
& 7 & 13.981 & 36.759 & 84.45 \\
& 9.4 & 22.343 & 32.578 & 74.46 \\
& 11 & 27.910 & 29.545 & 67.92 \\
$1,4 \mathrm{HAAB}$ & 4 & 1.986 & 42.507 & 97.72 \\
& 6 & 4.371 & 41.315 & 95.04 \\
& 7 & 5.413 & 40.793 & 93.78 \\
& 9.4 & 11.336 & 37.832 & 86.97 \\
& 11 & 16.136 & 35.432 & 81.45 \\
$1,2 \mathrm{HAAB}$ & 4 & 1.553 & 42.723 & 98.21 \\
& 6 & 2.593 & 42.204 & 97.02 \\
& 7 & 3.262 & 41.869 & 96.25 \\
& 9.4 & 4.582 & 41.209 & 94.73 \\
& 11 & 6.022 & 40.489 & 93.08 \\
$1,3 \mathrm{HAAB}$ & 4 & 2.656 & 42.172 & 96.95 \\
& 6 & 4.336 & 41.332 & 95.02 \\
& 7 & 5.311 & 40.844 & 93.89 \\
& 9.4 & 11.656 & 37.672 & 86.60 \\
& 11 & 17.913 & 34.544 & 79.4 \\
\hline & & & &
\end{tabular}

According to the results of Table 3, both adsorption efficiency and capacity estimated at equilibrium decreased with increasing the $\mathrm{pH}$ value of dye solution. The maximum removal of the tested dyes by CAC is observed at $\mathrm{pH}=4$, which may due to reduce of the negative charges on the carbon surface as a result of the excess of portions present in solution (Shukla et al., 2002). On the other hand, the basic medium increases the repulsion between the dye molecules and the negatively charged surface of carbon. This result is consistent with the results of other studies reported in the literature (EL-Ashtoukhy, 2009; Arami et al., 2005).

Effect of solvent. One of the main problem encountered this study is the weak solubility of the investigated dye 
in water. Ethanol was selected for this purpose because it is cheap, available and commonly used in various industries. Preliminary tests proved that, few milliliters of ethanol can dissolve the dye and dilution with water (to a certain limit) dose not affects the dye solubility in ethanol. Therefore, mixtures of ethanol-water were tested as dye solvent with varying ethanol ratio from $10-90 \%$. The effect of solvent with different ethanol ratio was estimated. The investigation was carried out using initial concentration $87 \mathrm{mg} / \mathrm{L}$ of dye solution at neutral medium $(\mathrm{pH}=7)$ and $20^{\circ} \mathrm{C}$, the results of this study are listed in Table (4).

Table 4. Effect of ethanol ratio on the adsorption efficiency, $\mathrm{C}_{\mathrm{i}}=87 \mathrm{mg} / \mathrm{L}$, temperature $=20^{\circ} \mathrm{C}$ and $\mathrm{pH}=7$

\begin{tabular}{|c|c|c|c|c|}
\hline Dye & $\%$ Ethanol & $\mathrm{C}_{\mathrm{e}}(\mathrm{mg} / \mathrm{L})$ & $\mathrm{q}_{\mathrm{e}}(\mathrm{mg} / \mathrm{g})$ & $\%$ Ads. \\
\hline \multirow[t]{5}{*}{1,4 DHAB } & 10 & 9.757 & 38.622 & 88.79 \\
\hline & 30 & 10.576 & 38.212 & 87.84 \\
\hline & 50 & 11.960 & 37.520 & 86.25 \\
\hline & 70 & 13.488 & 36.756 & 84.50 \\
\hline & 90 & 14.939 & 36.031 & 82.83 \\
\hline \multirow[t]{5}{*}{ 1,3 DHAB } & 10 & 10.080 & 38.460 & 88.41 \\
\hline & 30 & 10.945 & 38.028 & 87.42 \\
\hline & 50 & 12.517 & 37.242 & 85.61 \\
\hline & 70 & 14.115 & 36.443 & 83.78 \\
\hline & 90 & 15.752 & 35.624 & 81.89 \\
\hline \multirow[t]{5}{*}{ 1,4 HAAB } & 10 & 4.482 & 41.259 & 94.85 \\
\hline & 30 & 5.026 & 40.987 & 94.22 \\
\hline & 50 & 5.413 & 40.794 & 93.78 \\
\hline & 70 & 5.729 & 40.636 & 93.41 \\
\hline & 90 & 6.415 & 40.293 & 92.63 \\
\hline \multirow[t]{5}{*}{ 1,2 HAAB } & 10 & 2.660 & 42.170 & 96.94 \\
\hline & 30 & 2.990 & 42.005 & 96.56 \\
\hline & 50 & 3.301 & 41.850 & 96.21 \\
\hline & 70 & 3.748 & 41.626 & 95.69 \\
\hline & 90 & 4.233 & 41.384 & 95.13 \\
\hline \multirow[t]{5}{*}{ 1,3 НАAB } & 10 & 3.623 & 41.689 & 95.84 \\
\hline & 30 & 4.541 & 41.230 & 94.78 \\
\hline & 50 & 5.377 & 40.812 & 93.82 \\
\hline & 70 & 6.639 & 40.181 & 92.73 \\
\hline & 90 & 8.082 & 39.459 & 90.71 \\
\hline
\end{tabular}

The results of Table 4 showed that, the decrease of dielectric constant of the solvent (increase of ethanol ratio) decreases the adsorption efficiency and adsorption capacity. A solvent of $50 \%$ ethanol was used for achieving this study in order to ensure clear dye solution that stand for sufficient period without precipitation.
Effect of temperature. The Effect of temperature on adsorption is important for providing information regarding the nature of the studied system and the kind of forces controlling the adsorption process.

In this work, the effect of varying temperature on the adsorption of di-azo dyes on CAC is investigated in the range of $20-60{ }^{\circ} \mathrm{C}$ and at concentration of $87 \mathrm{mg} / \mathrm{L}$. The obtained results are listed in Table 5.

Table 5. Effect of temperature on adsorption efficiency of the tested dyes $\mathrm{Ci}=87 \mathrm{mg} / \mathrm{L}, \mathrm{pH}=7$

\begin{tabular}{llllll}
\hline \hline Dye & \multicolumn{5}{c}{ \% Adsorption } \\
\cline { 2 - 6 } & $20{ }^{\circ} \mathrm{C}$ & $30{ }^{\circ} \mathrm{C}$ & $40^{\circ} \mathrm{C}$ & $50{ }^{\circ} \mathrm{C}$ & $60^{\circ} \mathrm{C}$ \\
\hline 1,4 DHAB & 86.25 & 86.04 & 85.83 & 85.57 & 85.46 \\
1,3 DHAB & 85.61 & 85.40 & 85.08 & 84.82 & 84.60 \\
1,4 HAAB & 93.78 & 93.27 & 92.73 & 92.28 & 91.84 \\
1,2 HAAB & 96.21 & 85.58 & 95.11 & 94.44 & 93.95 \\
3 HAAB & 93.82 & 93.50 & 93.22 & 92.84 & 92.63 \\
\hline \hline
\end{tabular}

The results of Table 5 indicate the adsorption efficiency decreased with increasing the temperature in all of the studied dyes regardless of their straps. This observation is naturally acceptable since rising the temperature increases the desorption process.

Adsorption isotherms. Adsorption isotherms are usually used for describing the relationship between adsorbent and adsorbate at equilibrium. This relationship is expressed in terms of the ratio between the quantity of the adsorbed and remained solute in the solution at certain temperature at equilibrium.

Several models have been observed in the literature, applied to fit experimental data of adsorption in various systems.

In this work, the experimental data of the tested dyes were fitted to Freundlich, Langmuir and Tempkin isotherm equations.

Freundlich isotherm (Freundlich, 1906) is an empirical equation that can be applied to non-ideal adsorption systems involving heterogeneous adsorbent surface. It can be represented by the following linear form:

$$
\log \mathrm{q}_{\mathrm{e}}=\log \mathrm{K}_{\mathrm{f}}+\frac{1}{\mathrm{n}} \log \mathrm{C}_{\mathrm{e}}
$$

Where, $\mathrm{K}_{\mathrm{f}}(\mathrm{L} / \mathrm{g})$ and $\mathrm{n}$ are constant related to adsorption capacity and adsorption intensity, respectively. 
Their values can be calculated from the intercept and slope of the line plotted between $\log \mathrm{q}_{\mathrm{e}}$ versus $\log \mathrm{C}_{\mathrm{e}}$, respectively. The obtained values of $\mathrm{K}_{\mathrm{f}}$ and $\mathrm{n}$ are shown in Table 6.

The Langmuir isotherm (Woodard, 2001) can be expressed as in equation(El-Geundi, 1991). It suggests mono layer coverage of dye on adsorbent.

$$
\frac{\mathrm{C}_{\mathrm{e}}}{\mathrm{q}_{\mathrm{e}}}=\frac{1}{\mathrm{~K}_{\mathrm{L}} \cdot \mathrm{Q}_{\max }}+\frac{1}{\mathrm{Q}_{\max }} \mathrm{C}_{\mathrm{e}}
$$

Where, $\mathrm{C}_{\mathrm{e}}$ is the concentration of dye in the solution at equilibrium, $\mathrm{Q}_{\max }(\mathrm{mg} / \mathrm{g})$ and $\mathrm{K}_{\mathrm{L}}(\mathrm{L} / \mathrm{mg})$ are Langmuir constants related the maximum adsorption capacity and energy of adsorption, respectively.

The values of $\mathrm{Q}_{\max }$ and $\mathrm{K}_{\mathrm{L}}$ are estimated from the slope and intercept of the straight line plotted between $\mathrm{C}_{\mathrm{e}} / \mathrm{q}_{\mathrm{e}}$ against $\mathrm{C}_{\mathrm{e}}$, respectively. The values obtained are given in Table 6.

A dimensionless constant termed as separation factor $\left(R_{L}\right)$ can be deduced from the Langmuir isotherm data describing the essential under investigation. It can be defined by equation (12):

$$
\mathrm{R}_{\mathrm{L}}=\frac{1}{1+\mathrm{K}_{\mathrm{L}} \cdot \mathrm{C}_{\mathrm{O}}}
$$

Where, $\mathrm{C}_{\mathrm{o}}$ is the initial dye concentration, $\mathrm{K}_{\mathrm{L}}$ is the Langmuir constant which is related to the affinity of binding sites and is calculated by equation (13) shown below (Aksu, 2003).

$$
\mathrm{K}_{\mathrm{L}}=\mathrm{Q}_{\max } \times \mathrm{b}
$$

According to McKay et al., (1982) $\mathrm{R}_{\mathrm{L}}$ value refers to irreversible adsorption process when $\left(R_{L}=0\right)$, favourable $\left(0<\mathrm{R}_{\mathrm{L}}<1\right)$, linear $\left(\mathrm{R}_{\mathrm{L}}=1\right)$ or unfavourable $\left(\mathrm{R}_{\mathrm{L}}>1\right)$. The values of $K_{\mathrm{L}}$ obtained are shown in Table 7 .

The Tempkin isotherm (Thambavani and Sabitha, 2012) is presented as in equation (14):

$$
\mathrm{q}_{\mathrm{e}}=\mathrm{B}_{\mathrm{T}} \ln \mathrm{K}_{\mathrm{T}}+\mathrm{B}_{\mathrm{T}} \ln \mathrm{C}_{\mathrm{e}}
$$

Where,

$$
\mathrm{B}_{\mathrm{T}}=\mathrm{RT} / \mathrm{b}_{\mathrm{T}}
$$

$\mathrm{T}$ is the absolute temperature, $\mathrm{R}$ is the gas constant $(8.314 \mathrm{~J} / \mathrm{mol} / \mathrm{K}), \mathrm{b}_{\mathrm{T}}(\mathrm{J} / \mathrm{mol})$ is a constant related to the heat of adsorption and $\mathrm{K}_{\mathrm{T}}(\mathrm{L} / \mathrm{mg})$ is the equilibrium binding constant, and representing an indication on to the maximum binding energy.

The plot of $\mathrm{q}_{\mathrm{e}}$ against $\ln \mathrm{C}_{\mathrm{e}}$ can help for the determination of Tempkin constants, $\mathrm{K}_{\mathrm{T}}$ and $\mathrm{B}_{\mathrm{T}}$. The later enables the calculation of $b_{T}$. The results obtained from the application of Tempkin isotherm on the adsorption of the tested dye on CAC are presented in Table 6.

Looking at the results of Table 6, the following conclusion can be driven; the high correlation coefficient (R) values (0.992-0.999) obtained from the application of Freundlich model show that, it fits the experimental data better than the other isotherms. Good fit is also observed from applying Langmuir

\begin{tabular}{|c|c|c|c|c|c|}
\hline Isotherm & 1,4 DHAB & 1,3 DHAB & 1,4 HAAB & 1,2 HAAB & 1,3 HAAB \\
\hline \multicolumn{6}{|l|}{ Freundlich } \\
\hline $\mathrm{n}_{\mathrm{f}}$ & 1.243 & 1.364 & 2.057 & 2.298 & 2.001 \\
\hline $\mathrm{K}_{\mathrm{f}}$ & 4.990 & 5.591 & 17.282 & 24.400 & 15.513 \\
\hline $\mathrm{R}$ & 0.999 & 0.998 & 0.997 & 0.999 & 0.992 \\
\hline \multicolumn{6}{|l|}{ Langmuir } \\
\hline $\mathrm{b}(\mathrm{L} / \mathrm{mg})$ & 0.018 & 0.026 & 0.107 & 0.173 & 0.0940 \\
\hline $\mathrm{Q}_{\max }(\mathrm{mg} / \mathrm{g})$ & 212.766 & 153.846 & 11.047 & 121.951 & 117.647 \\
\hline $\mathrm{R}$ & 0.989 & 0.995 & 0.991 & 0.982 & 0.991 \\
\hline \multicolumn{6}{|l|}{ Tempkin } \\
\hline $\mathrm{B}_{\mathrm{T}}$ & 30.526 & 27.388 & 22.553 & 20.713 & 23.037 \\
\hline $\mathrm{K}_{\mathrm{T}}(\mathrm{L} / \mathrm{mg})$ & 0.354 & 0.379 & 1.574 & 3.555 & 1.257 \\
\hline $\mathrm{R}$ & 0.979 & 0.984 & 0.984 & 0.969 & 0.989 \\
\hline $\mathrm{b}_{\mathrm{T}}(\mathrm{J} / \mathrm{mol})$ & 79.800 & 88.944 & 108.012 & 117.607 & 105.743 \\
\hline
\end{tabular}
equation on the adsorption data of the studied dyes on $\mathrm{CAC}$ indicated by the values of $\mathrm{R}$ which are in range (0.982-0.995).

Table 6. Isotherms constants obtained from adsorption data of dyes on CAC at $20^{\circ} \mathrm{C}$ 
Although weaker values of correlation coefficients are obtained from the application of Tempkin isotherm on the adsorption data, its parameters can still provide valuable information since it dose not oppose the chemical intuition. Figs. 3-5 show the relations obtained from the fit of Freundlich, Langmuir and Tempkin isotherms, respectively.

The values of $n_{f}$ are higher than unity $\left(1<n_{f}<10\right)$, referring that, the adsorption of the investigated dyes on CAC is a favourable process (Khaled et al., 2009; Crini et al., 2007).

The values of maximum adsorption obtained from the fitting of Langmuir isotherm on the adsorption data lie in the range (119-212, $\mathrm{mg} / \mathrm{g})$, which are in agreement

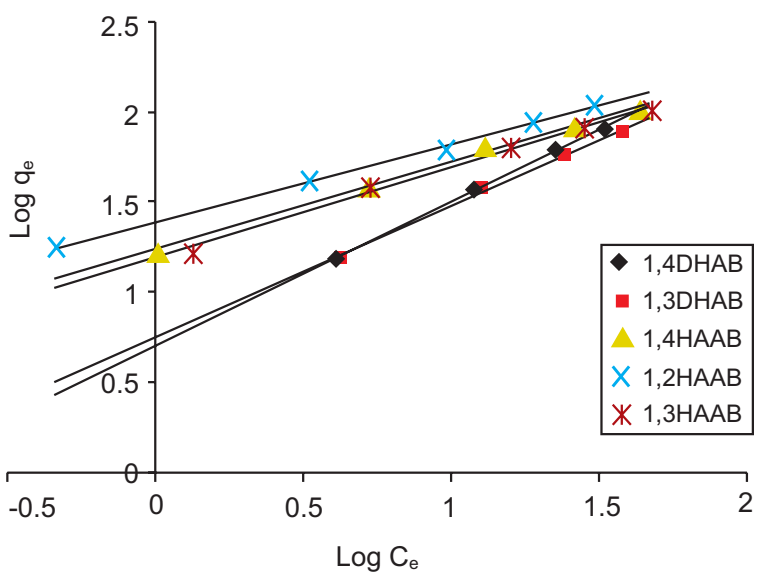

Fig. 3. Application of Freundlich isotherm on the adsorption data at $20^{\circ} \mathrm{C}$.

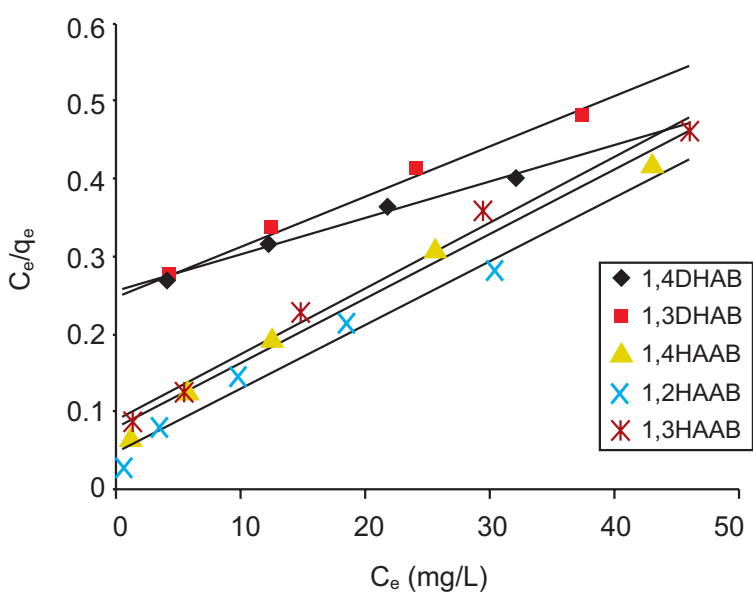

Fig. 4. Application of Langmuir isotherm on the adsorption data at $20^{\circ} \mathrm{C}$. with the results reported in the literature for similar studies (Khaled et al., 2009; Crini et al., 2007; Reddy et al., 2006).

The results listed in Table 7, explain that, all $\mathrm{R}_{\mathrm{L}}$ values calculated by employing equation (12), are greater than zero and less than unity, showing favourable adsorption of dye on CAC.

According to the results of applying Tempkin isotherm on the adsorption data on CAC, the values of the heat of adsorption $\left(\mathrm{b}_{\mathrm{T}}\right)$ decrease and the binding energies $\left(\mathrm{K}_{\mathrm{T}}\right)$ fall with surface coverage of the adsorbent due to the increase of adsorbate-adsorbate-interactions (Khaled et al., 2009).

Kinetic study. In this work, four models are employed for examining the controlling mechanism of adsorption process such as mass transfer and chemical reaction. The experimental data were analyzed by using the pseudo first order, pseudo second order, Elovich, and intraparticle diffusion kinetic models. The study is conducted at various initial dye concentrations (16$120 \mathrm{mg} / \mathrm{L})$, adsorbent dose $(2 \mathrm{~g} / \mathrm{L})$ and constant temperature $\left(20^{\circ} \mathrm{C}\right)$, as follow:

Pseudo first order model. According to this model (eq. 2), the value of $\mathrm{k}_{1}$ and $\mathrm{q}_{\mathrm{e}}$ are determined from the plot of $\log \left(\mathrm{q}_{\mathrm{e}}-\mathrm{q}_{\mathrm{f}}\right)$ versus time. Their values, the value of correlation coefficient and experimental $\mathrm{q}_{\mathrm{e}}$ are given in Table 8.

The results of Table 8 indicated that, this model cannot be applied for the entire adsorption process. This may

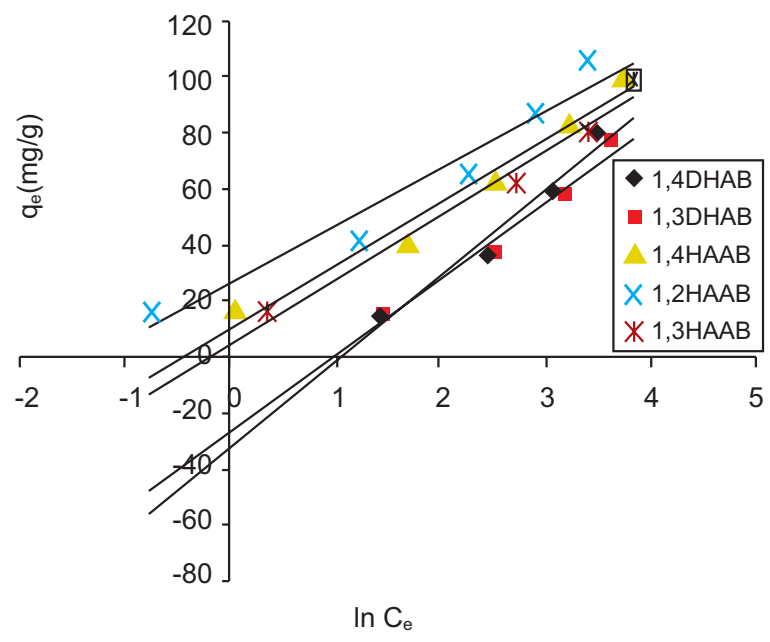

Fig. 5. Application of Tempkin isotherm on the adsorption data at $20^{\circ} \mathrm{C}$. 
Table 7. Values of $\mathrm{R}_{\mathrm{L}}$ and $\mathrm{b}$ obtained from the application of Langmuir isotherm at $20^{\circ} \mathrm{C}$

\begin{tabular}{|c|c|c|c|}
\hline Dye & B (L/mg) & $\mathrm{C}_{\mathrm{i}}(\mathrm{mg} / \mathrm{L})$ & $\mathrm{R}_{\mathrm{L}}$ \\
\hline 1,4 DHAB & 0.0184 & $\begin{array}{l}35 \\
87 \\
140 \\
192 \\
245\end{array}$ & $\begin{array}{l}0.6083 \\
0.3845 \\
0.2796 \\
0.2206 \\
0.1816\end{array}$ \\
\hline 1,3 DHAB & 0.0261 & $\begin{array}{l}35 \\
87 \\
140 \\
192 \\
245\end{array}$ & $\begin{array}{l}0.5226 \\
0.3057 \\
0.2149 \\
0.1664 \\
0.1352\end{array}$ \\
\hline 1,4 HAAB & 0.1074 & $\begin{array}{l}35 \\
87 \\
140 \\
192 \\
245\end{array}$ & $\begin{array}{l}0.2101 \\
0.0967 \\
0.0624 \\
0.0463 \\
0.0366\end{array}$ \\
\hline 1,2 HAAB & 0.1734 & $\begin{array}{l}35 \\
87 \\
140 \\
192 \\
245\end{array}$ & $\begin{array}{l}0.1415 \\
0.0622 \\
0.0396 \\
0.0292 \\
0.023\end{array}$ \\
\hline 1,3 HAAB & 0.0944 & $\begin{array}{l}35 \\
87 \\
140 \\
192 \\
245\end{array}$ & $\begin{array}{l}0.2323 \\
0.1085 \\
0.0703 \\
0.0523 \\
0.0414\end{array}$ \\
\hline
\end{tabular}

be attributed to the decrease in the adsorption rate (which is initially fast) due to pore diffusion (Eren and Acar, 2006; Ozacar and Sengil, 2003). For this reason, the calculated $\mathrm{q}_{\mathrm{e}}$ values are quite low if compared to the experimental $\mathrm{q}_{\mathrm{e}}$. Furthermore, the values of $\mathrm{R}$ for all of the plotted lines are far less than unity denoting that, the adsorption of the studied dyes on to CAC is not first order reaction.

Pseudo second order model. The experimental data of the adsorption of the diazo dyes on activated carbon are fitted to the Pseudo second order model (eq. 4). The values of $\mathrm{k}_{2}(\mathrm{~g} / \mathrm{mg} / \mathrm{min})$ and $\mathrm{q}_{\mathrm{e}}(\mathrm{mg} / \mathrm{g})$ are calculated from the slope and intercept of the straight lines obtained by plotting $\mathrm{t} / \mathrm{q}_{\mathrm{e}}$ against time (Fig. 6a-e), respectively. The initial rate of adsorption $(\mathrm{h}, \mathrm{mg} / \mathrm{g} / \mathrm{min})$, is evaluated using equation (12):

$$
\mathrm{h}=\mathrm{k}_{2} \mathrm{q}_{\mathrm{e}}^{2}
$$

The results obtained from the application of this kinetic model are portrayed in Table 9.

The results of Table 9 indicated that, contrary to the first order equation, this model fit the adsorption data well for the whole range of contact time. Excellent linear relationships obtained (Fig. 7) indicated by the values of correlation coefficients which found to be in

Table 8. Results of the fitting of the pseudo first order model on adsorption data, $\mathrm{pH}=7$ and $\mathrm{T}=20^{\circ} \mathrm{C}$

\begin{tabular}{|c|c|c|c|c|c|}
\hline Dye & $\mathrm{C}_{\mathrm{i}}(\mathrm{mg} / \mathrm{L})$ & $\mathrm{q}_{\mathrm{e}}$ calc $(\mathrm{mg} / \mathrm{g})$ & $\mathrm{k}_{1}(\min )$ & $\mathrm{q}_{\mathrm{e}} \exp (\mathrm{mg} / \mathrm{g})$ & $\mathrm{R}$ \\
\hline \multirow[t]{4}{*}{$1,4 \mathrm{DHAB}$} & 60 & -0.447 & 0.0378 & 25.847 & 0.6074 \\
\hline & 87 & - & 0.0113 & 37.737 & 0.2480 \\
\hline & 100 & -0.853 & 0.0412 & 42.304 & 0.5116 \\
\hline & 120 & - & 0.0299 & 50.720 & 0.4572 \\
\hline \multirow{4}{*}{$1,3 \mathrm{DHAB}$} & 60 & -0.306 & 0.0292 & 25.340 & 0.7549 \\
\hline & 87 & -0.560 & 0.0472 & 36.786 & 0.5361 \\
\hline & 100 & -0.944 & 0.0302 & 41.159 & 0.5208 \\
\hline & 120 & - & 0.0184 & 49.548 & 0.4399 \\
\hline \multirow[t]{4}{*}{$1,4 \mathrm{HAAB}$} & 60 & -0.482 & 0.0327 & 28.400 & 0.6181 \\
\hline & 87 & -0.377 & 0.0523 & 40.793 & 0.7232 \\
\hline & 100 & -1.241 & 0.0316 & 46.116 & 0.4641 \\
\hline & 120 & - & 0.0249 & 54.851 & 0.3939 \\
\hline \multirow[t]{4}{*}{$1,2 \mathrm{HAAB}$} & 60 & - & 0.027636 & 28.835 & 0.4954 \\
\hline & 87 & -0.440 & 0.036618 & 41.862 & 0.5093 \\
\hline & 100 & - & 0.025103 & 47.088 & 0.4706 \\
\hline & 120 & - & $-4.6 \mathrm{E}-05$ & 56.010 & 0.0008 \\
\hline \multirow[t]{4}{*}{ 1,3НAAB } & 60 & 0.134 & 0.0359 & 28.295 & 0.9654 \\
\hline & 87 & 0.124 & 0.0355 & 40.828 & 0.9670 \\
\hline & 100 & 0.120 & 0.0359 & 45.574 & 0.9707 \\
\hline & 120 & 0.114 & 0.0366 & 53.861 & 0.9768 \\
\hline
\end{tabular}



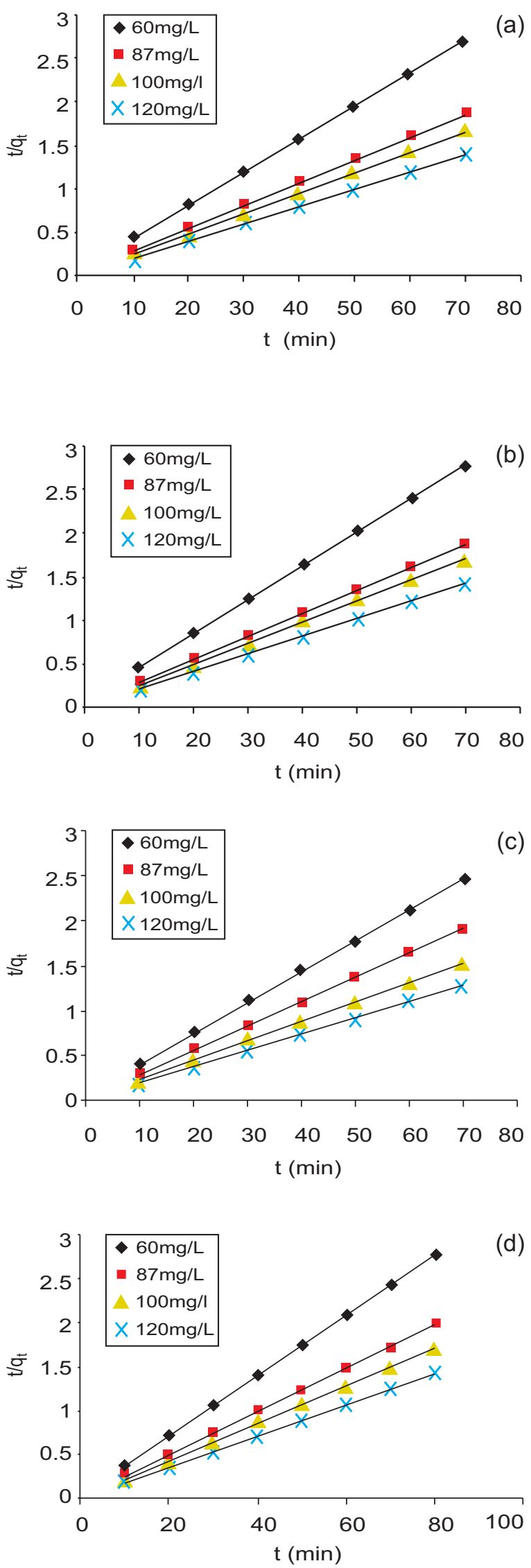

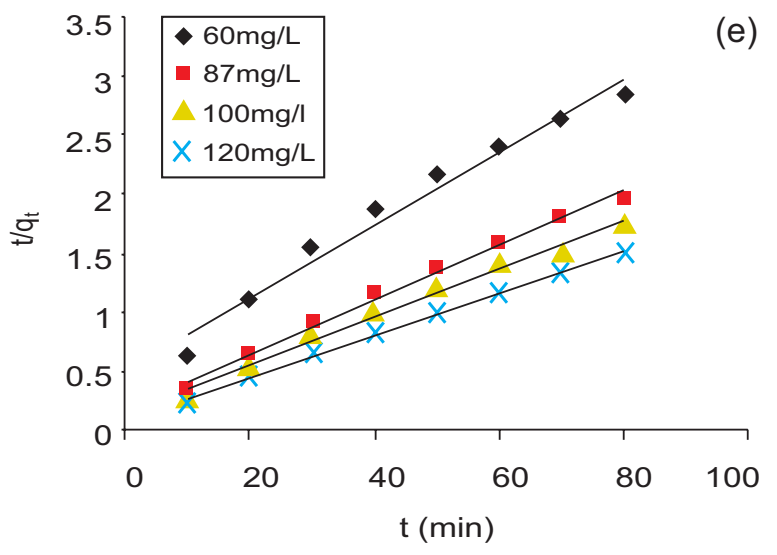

Fig. 6a-e. Relation between $\mathrm{t} / \mathrm{q}_{\mathrm{t}}$ versus time of the tested dye at different concentrations, (a) 1,4DHAB; (b) 1,3DHAB; (c) 1,4HAAB; (d) 1,2HAAB and (e) 1,3HAAB.

the range between $(0.98-1.0)$ for all of the dyes and at all concentrations. In addition, the values of calculated $\mathrm{q}_{\mathrm{e}}\left(\mathrm{q}_{\mathrm{e}}\right.$ calc.) agreed very well with the experimental $\mathrm{q}_{\mathrm{e}}$ $\left(q_{e}\right.$ exp) data. These results suggest that, the adsorption of the considered dyes on CAC obeys the second order kinetic model for the entire period of adsorptions based on the assumption that, the rate limiting step may involve chemisorptions. The investigation also revealed that, the increase of the initial concentration increases the initial rate of adsorption (h), since it enables the mass transfer of the adsorbate molecules from the solution to the solid surface of adsorbent. The results obtained are similar to data of other studies observed in the literature (EL-Nemr et al., 2009; Khaled et al., 2009).

Elovich kinetic model. This model (eq. 6) is fitted to the adsorption data of the studied dyes under similar conditions that used when applying the Pseudo first and second order models. The linear relationships between $\mathrm{q}_{\mathrm{t}}$ and lnt shown in (Fig. 8) are used to calculate the values of Elovich constant represented by the initial rate of adsorption ( $\alpha, \mathrm{mg} / \mathrm{g} / \mathrm{min})$ and desorption constant $(\beta, \mathrm{g} / \mathrm{mg})$. These constants were determined at various concentrations, from the slope and intercept of the straight lines (Fig. 8), respectively. The estimated values are listed in Table 10.

Increase in the initial rate of adsorption $(\alpha)$ is observed with the increase of initial concentration, accompanied by increase of desorption constant. These results can be interpreted as follow; as mentioned earlier, the increase of initial concentration facilitate the molecular 
Table 9. Results of the fitting of the pseudo second order model on adsorption data, $\mathrm{pH}=7, \mathrm{~T}=20^{\circ} \mathrm{C}$ and $\mathrm{CAC}$ dose $=2 \mathrm{~g} / \mathrm{L}$

\begin{tabular}{lllllll}
\hline \hline Dye & $\mathrm{C}_{\mathrm{i}}(\mathrm{mg} / \mathrm{L})$ & $\mathrm{q}_{\mathrm{e}}$ calc $(\mathrm{mg} / \mathrm{g})$ & $\mathrm{k}_{2}(\mathrm{~g} / \mathrm{mg} / \mathrm{min})$ & $\mathrm{H}(\mathrm{mg} / \mathrm{g} / \mathrm{min})$ & $\mathrm{q}_{\mathrm{e}} \exp (\mathrm{mg} / \mathrm{g})$ & $\mathrm{R}$ \\
\hline 1,4 DHAB & 60 & 26.315 & 0.0278 & 19.251 & 25.847 & 1 \\
& 87 & 38.167 & 0.0390 & 56.812 & 37.737 & 1 \\
& 100 & 42.553 & 0.0472 & 85.468 & 42.304 & 1 \\
1,3 DHAB & 120 & 51.020 & 0.0600 & 156.182 & 50.720 & 1 \\
& 60 & 25.906 & 0.0188 & 12.617 & 25.340 & 0.9998 \\
& 100 & 37.174 & 0.0387 & 53.480 & 36.786 & 1 \\
& 120 & 41.493 & 0.0443 & 76.270 & 41.159 & 1 \\
$1,4 \mathrm{HAAB}$ & 60 & 28.818 & 0.0546 & 135.144 & 49.548 & 1 \\
& 87 & 41.152 & 0.0283 & 23.503 & 28.400 & 1 \\
& 100 & 46.296 & 0.0451 & 76.376 & 40.793 & 1 \\
$1,2 \mathrm{HAAB}$ & 120 & 54.945 & 0.0518 & 111.024 & 46.116 & 1 \\
& 60 & 29.069 & 0.0705 & 212.836 & 54.851 & 1 \\
& 87 & 42.016 & 0.0595 & 50.278 & 28.835 & 1 \\
1,3 HAAB & 100 & 47.169 & 0.0671 & 103.096 & 41.862 & 1 \\
& 120 & 56.179 & 0.0792 & 149.292 & 47.088 & 1 \\
& 87 & 32.467 & 0.0013 & 249.962 & 56.010 & 1 \\
\hline \hline
\end{tabular}
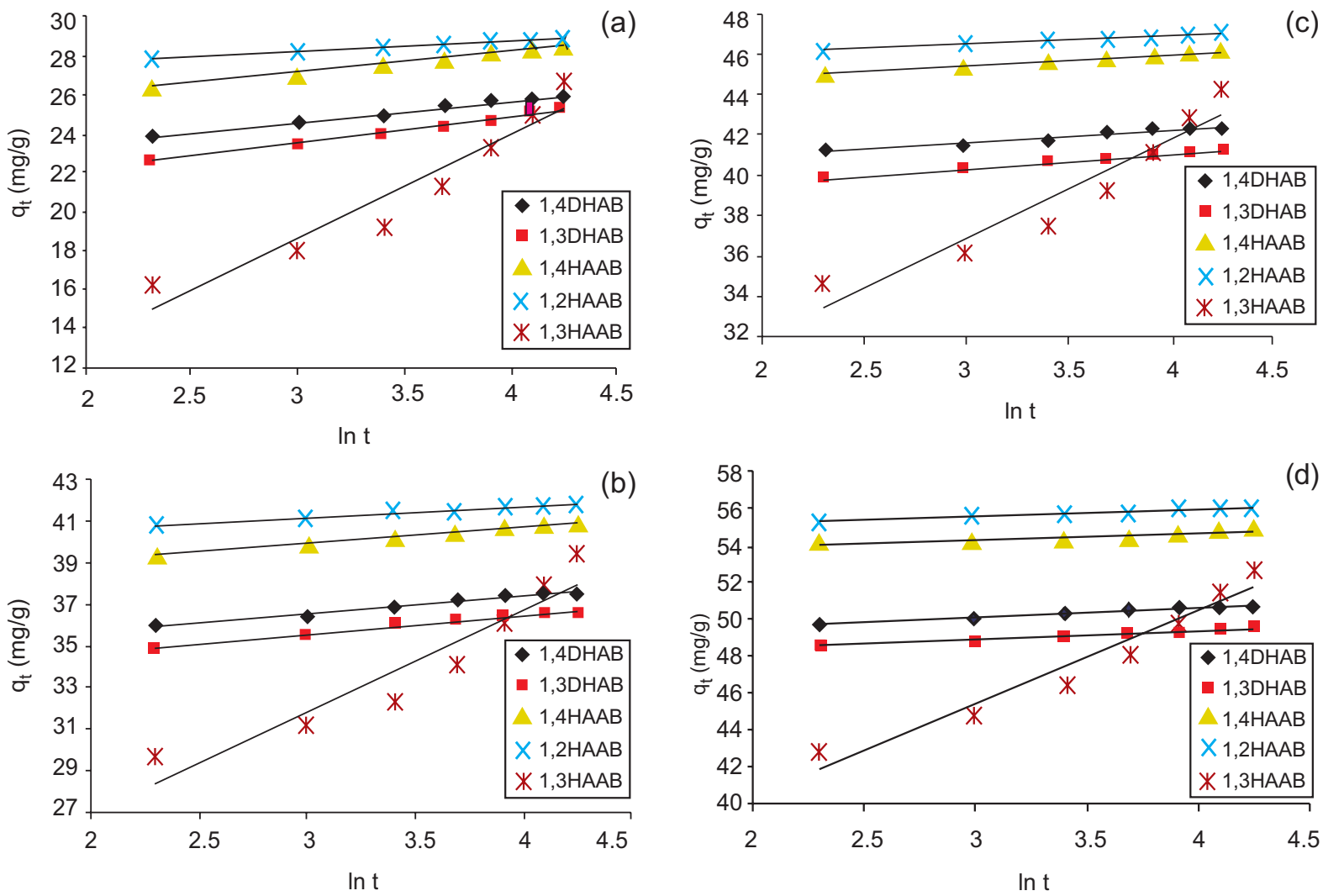

Fig. 7a-d. The relation between $\mathrm{q}_{\mathrm{t}}$ versus $\ln \mathrm{t}$ at different initial concentrations, (a) $60 \mathrm{mg} / \mathrm{L}$; (b) $87 \mathrm{mg} / \mathrm{L}$; (c) $100 \mathrm{mg} / \mathrm{L}$ and (d) $120 \mathrm{mg} / \mathrm{L}$. 

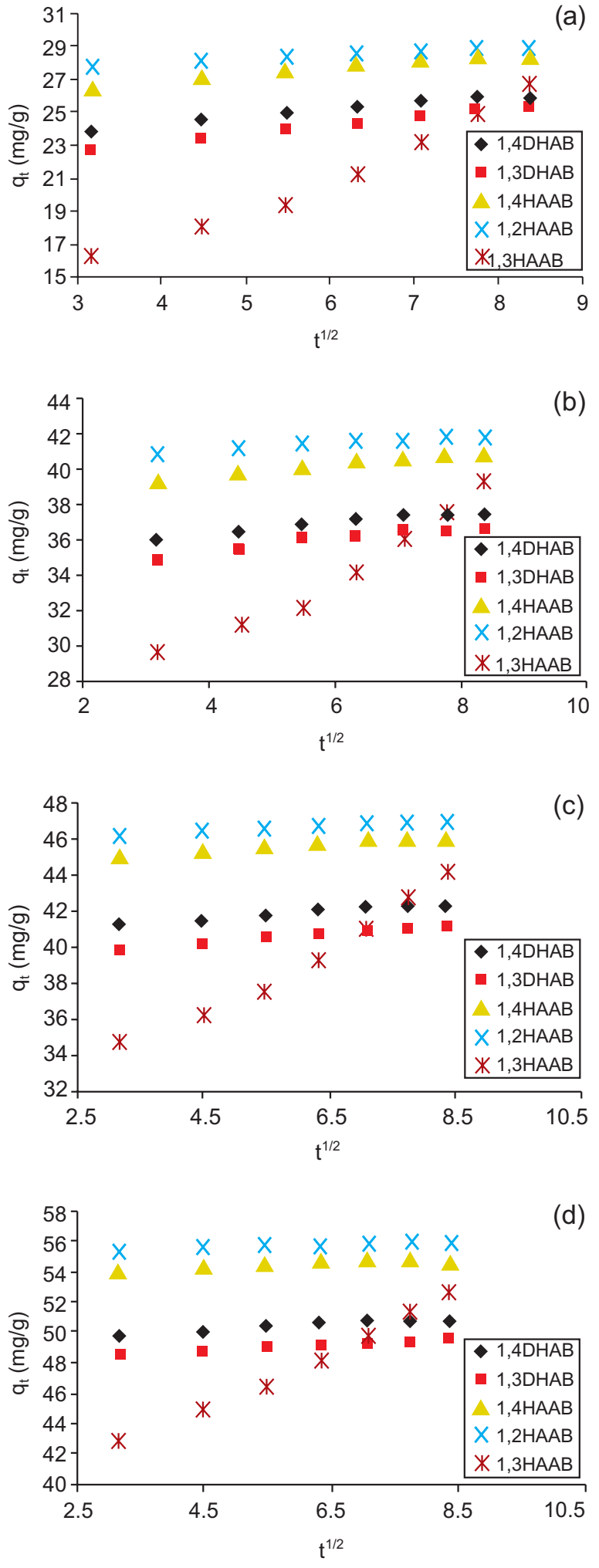

Fig. 8a-d. Relationship between $q_{t}$ versus $t^{1 / 2}$ at different initial concentrations, (a) $60 \mathrm{mg} / \mathrm{L}$; (b) $87 \mathrm{mg} / \mathrm{L}$; (c) $100 \mathrm{mg} / \mathrm{L}$ and (d) $120 \mathrm{mg} / \mathrm{L}$.
Table 10. Results of the application of Elovich equation on the adsorption data, $\mathrm{pH}=7, \mathrm{CAC}$ dose $=2 \mathrm{~g} / \mathrm{L}$ and $\mathrm{T}=20^{\circ} \mathrm{C}$

\begin{tabular}{lllll}
\hline \hline Dye & $\mathrm{C}_{\mathrm{i}}(\mathrm{mg} / \mathrm{L})$ & $\beta(\mathrm{g} / \mathrm{mg})$ & $\alpha(\mathrm{mg} / \mathrm{g} / \mathrm{min})$ & $\mathrm{R}$ \\
\hline $1,4 \mathrm{DHAB}$ & 60 & 0.927 & $4.344 \mathrm{E} 08$ & 0.9918 \\
& 87 & 1.211 & $9.464 \mathrm{E} 17$ & 0.9903 \\
& 100 & 1.402 & $6.706 \mathrm{E} 23$ & 0.9895 \\
& 120 & 1.793 & $2.793 \mathrm{E} 37$ & 0.9936 \\
$1,3 \mathrm{DHAB}$ & 60 & 0.720 & $1.603 \mathrm{E} 06$ & 0.9952 \\
& 87 & 1.090 & $4.145 \mathrm{E} 15$ & 0.9866 \\
& 100 & 1.384 & $6.287 \mathrm{E} 22$ & 0.9968 \\
& 120 & 1.926 & $1.914 \mathrm{E} 39$ & 0.9933 \\
$1,4 \mathrm{HAAB}$ & 60 & 0.959 & $1.053 \mathrm{E} 10$ & 0.9956 \\
& 87 & 1.318 & $2.723 \mathrm{E} 21$ & 0.9944 \\
& 100 & 1.791 & $6.007 \mathrm{E} 33$ & 0.9930 \\
& 120 & 2.569 & $8.182 \mathrm{E} 58$ & 0.9698 \\
$1,2 \mathrm{HAAB}$ & 60 & 1.857 & $1.407 \mathrm{E} 21$ & 0.9901 \\
& 87 & 1.968 & $4.278 \mathrm{E} 33$ & 0.9970 \\
& 100 & 2.318 & $1.400 \mathrm{E} 45$ & 0.9937 \\
& 120 & 2.881 & $5.789 \mathrm{E} 67$ & 0.9944 \\
$1,3 \mathrm{HAAB}$ & 60 & 0.172 & $1.105 \mathrm{E} 02$ & 0.9536 \\
& 87 & 0.184 & $1.011 \mathrm{E} 05$ & 0.9497 \\
& 100 & 0.187 & $6.003 \mathrm{E} 04$ & 0.9553 \\
& 120 & 0.186 & $7.545 \mathrm{E} 06$ & 0.9722 \\
\hline \hline & & & &
\end{tabular}

transfer on to the solid surface which leads to increase in the initial concentration due to the availability of active sites on the carbon surface in the first few minutes. As the coverage of carbon surface increase, the competition among adsorbate molecules to be attached on the limited number of active sites remained on the carbon surface increased, creating a repulsion forces toward the adsorbent surface which weaken the bonding energy and increasing the desorption process. This observation is consistent with other results found in the literature (EL-Nemr et al., 2009; Khaled et al., 2009).

The intraparticle diffusion model. The possibility of applying this model on the adsorption data of the studied azo dyes on CAC is tested in terms of the graphical relationship (eq. 7) between the amount of dye adsorbed and the square root of time.

The plot between $\mathrm{q}_{\mathrm{t}}$ against $\mathrm{t}^{1 / 2}$, shown in (Fig. 8), is found to give two lines. The rate of diffusion constant ( $\mathrm{K}_{\text {diff, }} \mathrm{mg} / \mathrm{g} / \mathrm{min}$ ) is directly estimated from the slope of the second regression line and the value of $\mathrm{C}$ is represented by the intercept.

The values of correlation coefficients, $\mathrm{K}_{\text {diff }}$ and $\mathrm{C}$ are given in Table 11. 
Table 11. Results of the application of the intraparticle diffusion model on adsorption data, $\mathrm{pH}=7, \mathrm{~T}=20^{\circ} \mathrm{C}$ and $\mathrm{CAC}$ dose $=2 \mathrm{~g} / \mathrm{L}$

\begin{tabular}{lllll}
\hline \hline Dye & $\mathrm{C}_{\mathrm{i}}(\mathrm{mg} / \mathrm{L})$ & $\begin{array}{l}\mathrm{K}_{\text {diff }} \\
(\mathrm{mg} / \mathrm{g} / \mathrm{min})\end{array}$ & $\mathrm{C}(\mathrm{mg} / \mathrm{g})$ & $\mathrm{R}$ \\
\hline 1,4DHAB & 60 & 0.3964 & 22.735 & 0.9852 \\
& 87 & 0.3020 & 35.399 & 0.9785 \\
& 100 & 0.2601 & 40.296 & 0.9745 \\
& 120 & 0.2031 & 49.138 & 0.9775 \\
$1,3 \mathrm{DHAB}$ & 60 & 0.5152 & 21.110 & 0.9984 \\
& 87 & 0.3298 & 34.265 & 0.9585 \\
& 100 & 0.2645 & 39.074 & 0.9863 \\
& 120 & 0.1932 & 47.954 & 0.9985 \\
$1,4 \mathrm{HAAB}$ & 60 & 0.3840 & 25.347 & 0.9907 \\
& 87 & 0.2761 & 38.646 & 0.9773 \\
& 100 & 0.2072 & 44.453 & 0.9952 \\
& 120 & 0.1473 & 53.637 & 0.9912 \\
$1,2 \mathrm{HAAB}$ & 60 & 0.1854 & 27.315 & 0.9632 \\
& 87 & 0.1774 & 40.383 & 0.9842 \\
& 100 & 0.1521 & 45.793 & 0.9932 \\
& 120 & 0.1214 & 55.002 & 0.9827 \\
& 60 & 2.1234 & 8.5916 & 0.9878 \\
& 87 & 1.9919 & 22.359 & 0.9856 \\
& 100 & 1.9500 & 27.601 & 0.9888 \\
& 120 & 1.9461 & 36.207 & 0.9963 \\
\hline
\end{tabular}

Figure 8 confirms that, the adsorption of the tested dyes on CAC vary in a similar trend. The two intersecting lines obtained in each plot indicate that, the adsorption mechanism includes two steps independent of each other. The first one is fast and representing the attachment of dye onto the external surface of carbon at the beginning of the adsorption process. The second step occurs with a slower rate in which the dye molecules diffuse into the pores exist on the carbon surface. Since the plots of $\mathrm{q}_{\mathrm{t}}$ versus $\mathrm{t}^{1 / 2}$ obtained for all of the dyes do not pass through the origin point, the intraparticle diffusion is not the rate limiting step, and the surface adsorption is operating concurrently during the dyecarbon interactions.

The values of the thickness of the boundary layer(C) were found to increase with the increase of initial concentrations, which reflect the decrease of probability of the external mass transfer and increasing the chance of internal transfer. This observation is supported by the values of the intraparticle diffusion constants $\left(\mathrm{K}_{\text {diff }}\right)$ which decrease with the increase of the initial dye concentrations. The main reason for such behaviour is the increase of adsorbate-adsorbate interactions that result from the increase of initial concentration (Kannan and Sundaram, 2001).

The linear relationships between $\mathrm{q}_{\mathrm{t}}$ and $\mathrm{t}^{1 / 2}$ based on the correlation coefficient values close to unity is a good indication of the application of this model on the studied systems and may confirm that, the intraparticle diffusion process is the rate determining step.

\section{Conclusion}

In this study, a number of di-azo dyes are synthesized. These dyes were of great stability and have properties that making them suitable for industrial application specially textile industry. The results of the investigation dealing with the methodology of treating the water pollution, that may occur as a result of throwing such dyes into water sources as an industrial waste, by adsorption.

The forces controlling the adsorption process and the mechanism by which the adsorption is performed are investigated by employing equilibrium and kinetic studies which are conducted at the optimal conditions of the adsorption system.

\section{References}

Ahmed, A.A., Hameed, B.H., Aziz, N. 2007. Adsorption of direct dye on palm ash: kinetic and equilibrium modeling. Journal of Hazardous Materials, 141: 70-76.

Aksu, Z. 2003. Reactive dye bioaccumulation by Saccharomyces cerevisiae. Process Biochemistry, 38: $1437-1444$.

AL-Abady, R.T.Gh. 2010. Thermodynamic and kinetic study of adsorption of di-azo dyes on activated carbon in aqueous solution. Ph.D. Thesis, pp. 57-59, Mosul University, Iraq.

AL-Hyali, E.A., Al-Jarjari, I.A. 2008. Study of the adsorption of some azo dyes on activated carbon. Journal of Education and Science, 21: 31-48.

Annadurai, G., Juang, R.S., Lee, D.J. 2002. Use of cellulose-based wastes for adsorption of dyes from aqueous solutions. Journal of Hazardous Materials, 92: 263-274.

Arami, M., Limaee, N.Y., Mahmoodi, N.M., Tabrizi, N.S. 2005. Removal of dye from colored textile wastewater by orange peel adsorbent: equilibrium and kinetic studies. Journal of Colloid and Interface Science, 288: 371-376.

Chien, S.H., Clayton, W.R. 1980. Application to Elovich equation to the kinetics of phosphate release and 
sorption on soils. Soil Science Society of America Journal, 44: 265-268.

Crini, G., Peindy, H.N., Gimbert, F., Robert, C. 2007. Removal of C.I. basic green 4 (Malachite green) from aqueous solutions by adsorption using cyclodextrin based adsorbent: kinetic and equilibrium studies. Separation and Purification Technology, 53: 97-110.

Dushenkov, V., Kumar, P.B.A.N., Motto, H., Raskin, I. 1995. Rhizofiltration: The use of plants to remove heavy metals from aqueous systems. Environmental Science and Technology, 29: 1239-1245.

El-Geundi, M.S. 1991. Homogeneous surface diffusion model for the adsorption of basic dyestuffs onto natural clay in batch adsorbers. Adsorption Science and Technology, 8: 217-225.

EL-Nemr, A., Abdelwahab, O., EL-Sikaily, A. 2009. Removal of direct blue- 86 from aqueous solution by new activated carbon developed from orange peel. Journal of Hazardous Materials, 161: 102-110.

EL-Ashtoukhy, el S.Z. 2009. Luffa aegyptiaca as a novel adsorbent for removal of direct blue dye from aqueous solution. Journal of Environment Management, 90: 2755-2761.

Eren, Z., Acar, F.N. 2006. Adsorption of reactive black 5 from aqueous solution: equilibrium and kinetic studies. Desalination, 194: 1-10.

Freundlich, H.M. 1906. Uber die adsorption in losungen. Zeitschrift fur Physikalsche Chemie, 57A: 385-470.

Hameed, B.H. 2009. Spent tea leaves: A new nonconventional and low cost adsorbent for removal of basic dye from aqueous solutions. Journal of Hazardous Materials, 161: 753-759.

Ho, Y.S. 2006. Review of second-order models for adsorption system. Journal of Hazardous Materials, 136: 681-689.

Ho, Y.S., Wase, D.A.J., Forster, C.F. 1996. Kinetic studies of competitive heavy metal adsorption by sphagnum moss peat. Environmental Technology, 17: 71-77.

Kannan, N., Sundaram, M.M. 2001. Kinetic and mechanism of removal of methylene blue by adsorption on various carbons: a comparative study. Dyes and Pigments, 51: 25-40.

Khaled, A., EL-Nemr, A., Sikaily, A., Abdelwahab, O. 2009. Removal of direct $N$ blue-106 from artificial textile dye effluent using activated carbon from orange peel: Adsorption isotherm and kinetic studies. Journal of Hazardous Materials, 165: 100110.
Lagergren, S. 1898. Zur theorie der sogenannten (About the theory of so-called adsorption of solubale substances). Kungliga Svenska Vetenskapsakademiens. Handlingar, 24: 1-39.

Lewis, D.M. 1999. Coloration for the next century. Rewiew of Progress in Coloration and Related Topics, 29: 23-28.

Malik, P.K. 2003. Use of activated carbons prepared from sawdust and rice husk for adsorption of acid dyes: A case study of acid yellow 36. Dyes and Pigments, 56: 239-249.

McKay, G., Ho, Y.S. 1999. Pseudo second order model for adsorption process. Process Biochemistry, 34: 451-465.

McKay, G., Blair, H.S., Gardner, J.K. 1982. Adsorption of dyes on chitin: Equilibrium study. Journal of Applied Polymer Science, 27: 3043-3057.

Mohorcic, M., Friedrich, J., Pavko, A. 2004. Decoloration of the di-azo dyes reactive black 5 by immobilized Bjerkandera adusta in a stirred tank bioreactor. Acta Chimica Solvenica, 51: 619-628.

Ozacar, M., Sengil, I.A. 2003. Adsorption of reactive dyes of calcined alunite from aqueous solutions. Journal of Hazardous Materials, 98: 211-224.

Reddy, S.S., Kotaiah, B., Reddy, N.S.P., Velu, M. 2006. The removal of composite reactive dye from dyeing unit effluent using sewage sludge derived activated carbon. Turkish Journal of Engineering and Environmental Sciences, 30: 367-373.

Shah, B.A., Shah, A.V., Singh, R.R. 2009. Sorption isotherms and kinetics of chromium uptake from wastewater using natural sorbent material. International Journal of Environmental Science and Technology, 6: 77-90.

Sharma, I., Goyal, D. 2009. Kinetic modeling: Chromium(III) removal from aqueous solution by microbial waste biomass. Journal of Scientific and Industrial Research, 68: 640-646.

Shukla, A., Zhang, Y.H., Dubey, P., Margrave, J.L., Shukla, S.S. 2002. The role of saw dust in removal of unwanted materials from water. Journal of Hazardous Materials, B95: 137-152.

Slokar, Y.M., Le Marechal, M. 1998. Method of decoloration of textile wastewaters. Dyes and Pigments, 37: 335-357.

Smith, B., Koonce, T., Hudson, S. 1993. Decolorizing dye wastewater using chitosan. American Dyestuff Reporter, 82: 18-36.

Suteu, D., Bilba, D. 2005. Equilibrium and kinetic study of reactive dye brilliant red HE-3B adsorption by 
activated charcoal. Acta Chimica Solvenica, 52: 73-79.

Sutherland, J.B. 2004. Degradation of hydrocarbons by yeast and filamentous fungi. In: Fungal Biotechnology in Agricultural, Food and Environmental Applications, D. K. Arora, (ed.), pp. 457-469, Marcel Decker Inc., New York, USA.

Thambavani, D.S., Sabitha, M.A. 2012. Kinetic and isotherm studies of biodegradation on sugar mill waste water using Mangifera indica leaf powder. Research Journal of Pharmaceutical, Biological and Chemical Sciences, 3: 247-260.

Van der Zee, F.P. 2002. Anaerobic Azo Dye Reduction. Ph.D. Thesis, 8 pp., University of Wageningen, The Netherlands.

Vandevivere, P.C., Bianchi, R., Verstraete, W. 1998. Treatment and reuse of wastewater from the textile wet processing industry: Review of emerging technologies. Journal of Chemical Technology and Biotechnology, 72: 289-302.

Volgel, A. 1964. A Textbook of Practical Organic
Chemistry, pp. 622-623, $3^{\text {rd }}$ edition, Longmans, Green and Co. Ltd., London, UK.

Wallace, T.H. 2001. Biological Treatment of a Synthetic Dye Water and an Industrial Textile Wastewater Containing Azo Dyes Compounds. M.Sc. Thesis, pp. 4-13, Blacksburg, Virginia, USA.

Weber, W.J., Morris, J.C. 1963. Kinetics of adsorption on carbon from solution. Journal of Sanitary Engineering Division, American Society of Civil Engineering, 89: 31-59.

Woodard, F. 2001. Industrial Treatment Handbook. pp. 376-451, Butterworth-Heinemann, Publisher, UK.

Yasin, Y., Hassein, M.Z., Ahmed, F.H. 2007. Adsorption of methylene blue onto treated activated carbon. The Malaysian Journal of Analytical Science, 11: 400-406.

Yu, L.J., Shukla, S.S., Dorris, K.L., Shukla, A., Margrave, J.L. 2003. Adsorption of chromium from aqueous solutions by maple sawdust. Journal of Hazardous Materials, B100: 53-63. 